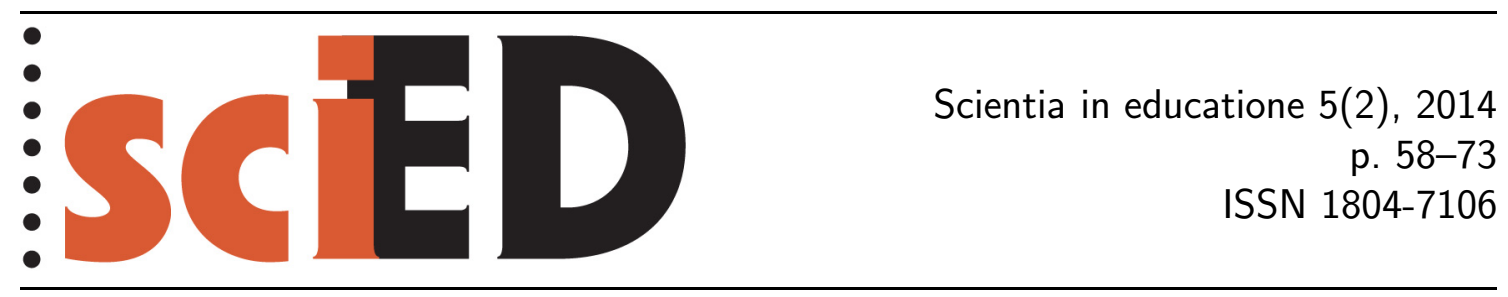

\title{
Výzkum pomocí oční kamery ve fyzikálním vzdělávání
}

\author{
Martina Kekule
}

\begin{abstract}
Abstrakt
Rešeršní článek představuje metodu oční kamery a její využití ve výzkumech ve fyzikálním vzdělávání. Oční kamera se poměrně často využívá ve výzkumu marketingu, medicíně, výzkumu čtení, vzdělávání sportovců apod.; v oblasti fyzikálního vzdělávání je použití této výzkumné metody poměrně vzácné. Článek uvádí přehled pěti studií, které se zaměřily na př́stupy žáků při řešení úloh z mechaniky nebo elektřiny a magnetismu. Navíc uvádí jednu studii z oblasti vzdělávání v biologii. Metoda byla použita jak pro kvalitativní, tak pro kvantitativní typ výzkumu. Nejčastěji byly porovnávány charakteristiky očního zkoumání vizuálního materiálu pro výkonově různě úspěšné skupiny žáků. Zkoumáni byli studenti převážně z VŠ v počtu 11-43. Získané výsledky naznačují několik rozdílů v př́stupu mezi žáky s horším a lepším výkonem. Limity metody jsou uvedeny v závěrečné části.
\end{abstract}

Klíčová slova: oční kamera, fyzikální vzdělávání, fyzika, mechanika, elektřina a magnetismus, řešení úloh.

\section{Eye-Tracking Research Method in Physics Education Research}

\begin{abstract}
The paper presents eye-tracking research method and its use in physics education research. The method is widely used in marketing, reading research, in sportsmen education etc., however in PER it is rarely used. The paper presents five studies (and one more from biology education), which concerned students' problem solving (mechanics and electricity). The method was used for both qualitative and quantitative form of research. The most often used comparison of characteristic connected with eye focus was provided. Students prevalently studying at universities were tested; a number of a sample ranged 11-43. The results show several differences between high and low performing students. Limits of the method are presented as well.
\end{abstract}

Key words: eye-tracker, physics education, mechanics, electricity and magnetism, problem solving. 


\section{1 ÚvOD}

Cílem článku je představit metodu výzkumu pomocí oční kamery (angl. eye-tracker) a její aplikace ve výzkumu fyzikálního vzdělávání. Oční kamera umožňuje sledovat pohyb očí pokusné osoby při prohlížení obrázku, čtení textu, sledování videa nebo při pohybu v nějaké reálné situaci (např. ve třídě). Konkrétně můžeme pomocí kamery „objektivně sledovat kognitivní pochody zkoumané osoby: jaké podněty vyhledávala, v jakém pořadí je studovala, kolik času jim věnovala a zda se k nim vracela“ (Lukavský, 2005). Oční kamera se poměrně často využívá ve výzkumu v marketingu nebo v medicíně; v oblasti vzdělávání pak zejména při výzkumu čtení a vzdělávání sportovců; pro zkoumání obecných dovedností/strategií při poznávání tuto metodu využívá kognitivní psychologie. Jak uvádí Duchowski (2002), úplné začátky této metody (angl. eye-tracking) spadají už do konce 19. stol. Moderní bezbolestné přístroje se použivají přibližně od 70. let minulého století. V oblasti výzkumu fyzikálního vzdělávání jsou studie prováděné pomocí oční kamery velmi vzácné (Smith, 2010) a to nejen v ČR, ale i v celosvětovém měřítku. Vzhledem k tomu, že je metoda zřejmě užitečně využívána $\mathrm{v}$ různých oblastech zabývajících se vzděláváním, může být přínosné začlenit ji i do výzkumu výuky přirodovědných předmětů. $\mathrm{V}$ článku je nejprve stručně představena metoda a přesnost sběru dat a dále jsou prezentovány konkrétní prŕklady aplikace této metody ve výzkumu v oblasti př́rodovědného/fyzikálního vzdělávání. Důraz je kladen zejména na představení možných výzkumných př́stupů.

\section{SLEDOVÁNí OČNÍCH POHYBƯ JAKO METODA VÝZKUMU}

\subsection{PRINCIP METODY}

Při použití oční kamery sledujeme pozici očí zkoumané osoby při pohledu na konkrétní prezentovaný vizuální materiál (obrázek, text, video apod.). Ve většině případů bude proband sledovat oblast zájmu tak, aby obraz dopadal na sítnici na oblast nejostřejšího vidění, což je právě zaznamenaná pozice očí. Nicméně předpoklad, že pokusná osoba zaměřuje pozornost právě na toto místo, nemusí být vždy správný. Jak naznačuje např. holistický model vnímání obrazového materiálu, experti nepotřebují klíčovou informaci zobrazit pomocí nejostřejší oblasti vidění, ale jsou schopni získat informaci i ze vzdálených oblastí neostrého vidění. V rámci ostrých oblastí vidění rozlišujeme na sítnici tři části: foveolu (průměr $0,4 \mathrm{~mm}$ ); foveu (průměr $1,5 \mathrm{~mm}$ ) a žlutou skvrnu/maculu (průměr $5 \mathrm{~mm}$ ). Tyto oblasti po řadě odpovídají $1,3^{\circ}, 5^{\circ}$ a 16,7 zorného pole (Duchowski, 2006). Obvykle se za oblast nejostřejšśho vidění považuje oblast do $1^{\circ}$ zorného pole. Tab. 1 uvádí přehled velikosti plošky (charakterizované průměrem), kterou na monitoru vnímá pokusná osoba ostře. V pásmu nejostřejšího vidění je kruh s poloměrem cca 1-1,5 cm. Vymezení konkrétní oblasti při pohledu na graf v úloze uvádí obr. 1 . Výsledky použité metody jsou tedy ovlivněny nejen přesností záznamu techniky (hraje roli zejména $\mathrm{v}$ př́padě interaktivních aplikací), ale při jejich interpretaci je také nutné brát v úvahu mechanismus vidění probanda. Dále výstupy ovlivňuje algoritmus použitý pro zpracování vstupních dat (identifikování fixací - viz dále).

Frekvence snímání očí závisí na typu kamery, běžně se využívá $60 \mathrm{~Hz}, 300 \mathrm{~Hz}$, pro výzkumy čtení $500 \mathrm{~Hz}$. Například při frekvenci $300 \mathrm{~Hz}$ je zaznamenána poloha očí 
Tab. 1: Velikost plošky na monitoru, kterou pokusná osoba sedící v různé vzdálenosti od prezentovaného média vnímá ostře

\begin{tabular}{cccc}
\hline úhel $\left[{ }^{\circ}\right]$ & úhel $[\mathrm{rad}]$ & vzdálenost k obrazovce $[\mathrm{cm}]$ & průměr plošky $[\mathrm{cm}]$ \\
\hline 1,3 & 0,0227 & 50 & 1,13 \\
\hline 1,3 & 0,0227 & 65 & 1,47 \\
\hline 1,3 & 0,0227 & 70 & 1,59 \\
\hline 5,0 & 0,0873 & 50 & 4,36 \\
\hline 5,0 & 0,0873 & 65 & 5,67 \\
\hline 5,0 & 0,0873 & 70 & 6,11 \\
\hline
\end{tabular}

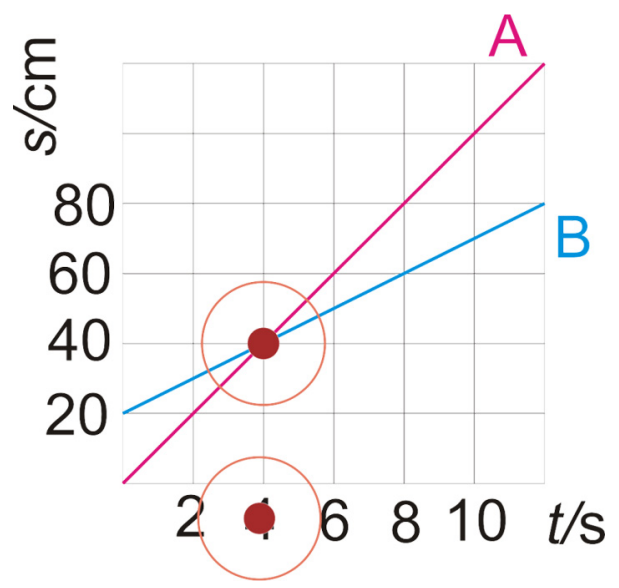

Obr. 1: Ilustrace oblasti nejostřejšího vidění (foveola červený kruh, fovea oranžová kružnice) při pohledu na průsečík křivek $\mathrm{A}$ a $\mathrm{B}$ a na číslici 4 na grafu při konkrétním experimentu

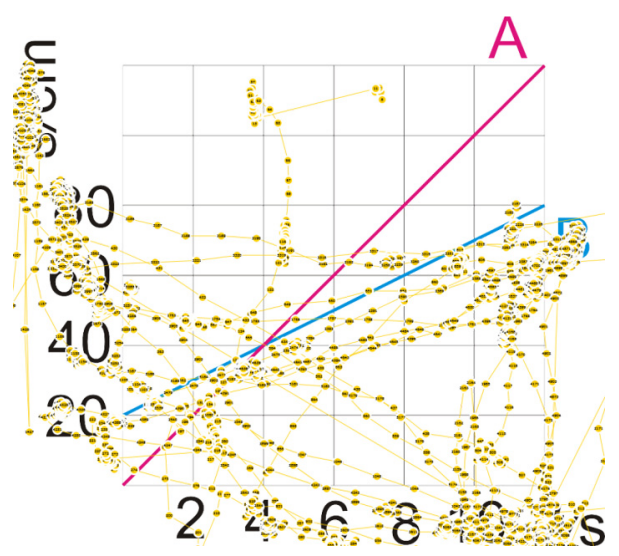

Obr. 2: Vyznačení pozic očí zaznamenaných během experimentu (tzv. gaze plot) pro hrubá data (experiment byl proveden autorkou článku pomocí oční kamery Tobii TX300)

každé 3,3 ms. Vyznačení jednotlivých pozic očí během experimentu, kdy pokusná osoba sledovala graf uvedený v obr. 1, ilustruje obr. 2. Při zvětšení jsou patrná i pořadová čísla jednotlivých pozic.

Pozice očí nicméně nezaručuje, že pokusná osoba vnímala dané místo na obrázku. Podle teorie vidění rozlišujeme dva základní pohyby očí při sledování nepohybujícího se objektu: fixace a sakády. Zaměřenou oblast vnímáme pouze v období fixace; sakáda je přesun oka $\mathrm{k}$ dalšímu fixovanému místu. Fixace by měla trvat nejméně $50 \mathrm{~ms}$, 
aby mohlo dojít k získání vizuálních informací (Lukavský, 2005). Dle Duchowského (2006) se fixace běžně pohybují v rozmezí 150-600 ms. Průměrně se udává, že fixace trvají 250-300 ms (Lukavský, 2005). Z hrubých dat je tedy nutné určit, které polohy očí příslušely fixacím a které sakádám. V závislosti na použitém algoritmu dostaneme např́klad obr. 3. V tomto případě byl použit IVT filtr na fixace dostupný v softwaru Tobii Studio 3.2. Podstatou algoritmu je vytipování sakadických pohybů očí na základě překročení určité rychlosti pohybu očí. Zde konkrétně 30 \% s. Součástí algoritmu je také redukce šumu, který vzniká např́klad mikrotřesem očí apod.

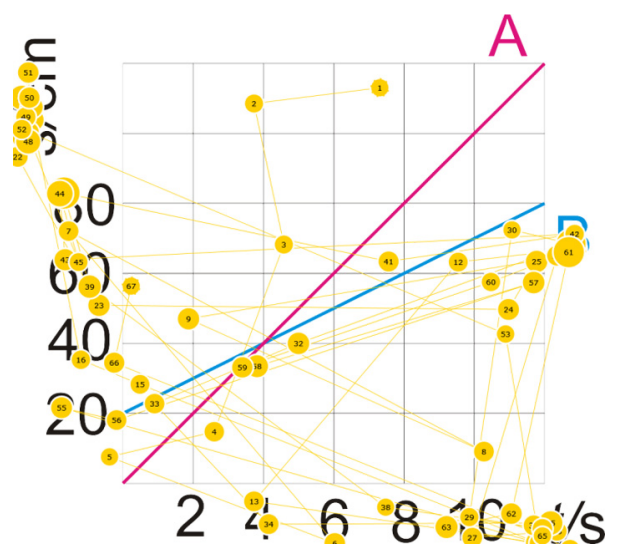

Obr. 3: Vyznačení pozic očí zaznamenaných během experimentu (tzv. gaze plot) s použitím konkrétního filtru na fixace. Průměr kruhu zohledňuje dobu trvání fixace (experiment byl proveden autorkou článku pomocí oční kamery Tobii TX300)

\subsection{VÝZKUMNÉ POUŽití METODY}

Metodologicky je možné oční kameru použít jak pro kvantitativní, tak pro kvalitativní typ výzkumu. Při kvalitativním typu výzkumu se využívají diagramy zobrazující fixace probanda při pohledu na prezentované médium (tzv. gaze plot). A to bud'to $\mathrm{v}$ animované podobě, kde se jedná o náhled fixací probanda v čase, nebo v sumarizované podobě jako obrázek (viz obr. 3). V přírodovědném vzdělávání je možné diagramy využít např. při posuzování webových stránek, dalších výukových materiáli̊ včetně učebnic, videí s nahranými experimenty apod. Další možností je využití tzv. heat map, tedy obrázků s vyznačením ploch, které proband/probandi fixovali nejvíce (nejdelší dobu/nejčastěji). V přírodovědném vzdělávání tento přístup můžeme opět využít pro posuzování uvedená v předchozím bodě, dále např́iklad při hlubší analýze strategií řešení problémových úloh apod.

V kvantitativním typu výzkumu se nejčastěji využívá nadefinovaných oblastí zájmu (area of interest/region of interest, zkratka AOI/ROI) a ke statistickému ověřování se používají data uvedená v tab. 2. Dále je možné sledovat změnu průměru zornice, což může indikovat změnu osvětlení, emocionality podnětu, pozornosti, zátěže pracovní paměti apod.

Typické úlohy probandi̊, pro které se metoda v dalších oborech využívá, lze základně rozdělit na diagnostické a interaktivní (Duchowski, 2002). V rámci diagnostických úloh jsou sledovány oční pohyby při pohledu probanda zejména na statický podnět, případně video. Tyto úlohy mohou obsahovat nějaké úkoly $\mathrm{k}$ vyřešení (např. čtení textu, vyhledání požadovaného objektu v obrázku) nebo mohou sledovat pouze volné prohlížení daného podnětu. Bojko (2013) zde rozlišuje cíl výzkumu, kdy může být sledována bud'to atraktivnost podnětu pro probanda nebo jeho výkon. V prvním př́padě se typicky zjištuje průměr pupily, počet fixací na 
Tab. 2: Typické proměnné sledované při kvantitativním výzkumu pomocí definovaných oblastí zájmů na prezentovaném médiu

\begin{tabular}{lll}
\hline Fixace v dané oblasti & $\begin{array}{l}\text { Prohlížení dané } \\
\text { oblasti }\end{array}$ & $\begin{array}{l}\text { Kliknutí myší v dané } \\
\text { oblasti }\end{array}$ \\
\hline $\begin{array}{l}\text { čas do první fixace v dané } \\
\text { oblasti }\end{array}$ & $\begin{array}{l}\text { čas strávený na dané } \\
\text { oblasti při jednom } \\
\text { souvislém prohlížení }\end{array}$ & $\begin{array}{l}\text { čas do prvního kliknutí } \\
\text { myší }\end{array}$ \\
\hline počet fixací předtím & $\begin{array}{l}\text { celkový čas strávený } \\
\text { prohlížením dané oblasti }\end{array}$ & počet kliknutí myší \\
\hline doba trvání první fixace & & procento z tohoto počtu \\
\hline $\begin{array}{l}\text { průměrná doba trvání } \\
\text { fixace v dané oblasti }\end{array}$ & \\
\hline celková doba trvání fixací & \\
\hline počet fixací & \\
\hline procento z tohoto počtu & \\
\hline
\end{tabular}

danou oblast, procento probandů, kteří si oblasti všimli apod. V druhém př́ipadě např́klad při měření mentální zátěže opět sledujeme průměr pupily; při sledování kognitivních procesů se zjištuje průměrná doba trvání fixace. Pokud je cílem úlohy vyhledání klíčového prvku, pak se jako vhodných proměnných využívá čas do první fixace na tento prvek, počet fixací předtím atp. Oční kameru je také možné využít ke sledování reálné scény (např. při řízení, vyhledávání zboží v obchodě, sledování výuky učitelem/žákem) s použitím přenosných brýlí. Ve všech těchto případech slouží oční kamera k rozpoznání, kam byla směřována pozornost probanda. V další části prezentované výzkumy se v podstatě týkají pouze tohoto typu úloh.

Interaktivní úlohy využívají zaznamenanou pozici očí, jak už název metody napovídá, k interakci s prezentovaným prostředím. Duchowski (2002) tyto metody dále dělí na selektivní a tzv. gaze-contingent. V případě selektivních metod je pohled očí využíván jako např. myš nebo klávesnice k ovládání daného prostředí. V rámci výzkumů typu gaze-contingent je prostředí měněno v závislosti na pohledu probanda. Velmi často se používá ve výzkumech čtení, např. Miellet et al. (2009) při čtení probandů měnili velikost písmen nacházejících se v oblastech mimo ostré vidění (fixaci) probanda.

\section{3 „EXPERT-ZAČÁTEČNÍK“ PARADIGMA}

Studie využívající metodu oční kamery jako výzkumnou metodu velmi často pracují v paradigmatu začátečník-expert (angl. expert-novices paradigm), kdy předpokládáme odlišný přístup experta a začátečníka při řešení daného úkolu. Jak uvádí Gegenfurtner (2011), představy o fungování perceptuálních mechanismů, které se skrývají za výkony expertů, byly uvedeny zejména v rámci studií o sportovních disciplínách, medicíně, o řízení auta, klasifikace ryb, v uměleckých oborech apod. Gegenfurtner (2011) identifikoval v realizovaných studiích tři teorie vysvětlující expertství:

- teorie dlouhodobé pracovní paměti, která předpokládá možnost rychlého zakódování získávané informace v dlouhodobé paměti experta a efektivní vybavení při dalších úlohách; operacionálně by se tento mechanismus měl projevit v kratší době trvání fixací v případě expertů; 
- hypotéza redukce informací, která navrhuje, že expert eliminuje nepodstatné informace a celkově tak pracuje s menším množstvím, ale za to relevantních informací; operacionálně by pak experti měli vykazovat méně a kratší fixace na oblasti nedůležité pro řešení daného problému a naopak by měli vykazovat více a delší fixace na oblasti relevantní pro vyřešení problému;

- holistický model vnímání obrazového materiálu, který uvádí, že experti nepotřebují klíčovou informaci zobrazit pomocí nejostřejší oblasti vidění, ale rozšiřrením oblasti efektivního vidění (angl. visual span) jsou schopni získat informaci i ze vzdálených oblastí neostrého vidění; operacionálně lze u expertů zaznamenat delší sakády a kratší čas do první fixace oblasti, která je relevantní pro řešení daného úkolu.

Výše uvedené expertství předpokládá častou práci s daným vizuálním materiálem, která má zřejmě za následek zlepšení schopnosti vnímání těchto materiálů a efektivnější extrahovaní klíčových informací. V oblasti zejména fyzikálního vzdělávání se často využivá metody oční kamery k odhalování žákovských strategií a přístupů při řešení úloh. Zde je pak expertství uvažováno v širším kontextu a zahrnuje celý proces řešení problému. Typické rozdíly mezi přístupem experta a začátečníka při řešení problémů uvádí např́́klad Gerace (2001). Experti vycházejí z konceptuálního porozumění problému, často nejprve řeší problém kvalitativně na rozdíl od začátečníků, kteří se zaměřují na manipulaci se vzorečky. Experti při řešení divergují, zvažují různé možnosti, ověřují si získaný výsledek alternativním postupem apod. Z hlediska deklarativních znalostí se experti vyznačují zejména velkou provázaností vlastních znalostí a jejich dobrou strukturací.

\section{PřEHLED REALIZOVANÝCH VÝZKUMŮ VE FYZIKÁLNÍM VZDĚLÁVÁNÍ}

Jak uvádí Smith (2010), publikovaných studií, které by popisovaly výzkum v oblasti fyzikálního vzdělávání realizovaný pomocí metody oční kamery, je velmi málo. Konkrétně se odkazuje na pět studií; v tomto článku je ještě navíc uvedena studie z oblasti biologie, která může být inspirativní z metodologického hlediska. Vzhledem $\mathrm{k}$ tak malému počtu publikací jsou dále prezentována pouze stručná souhrnná data a do̊raz je kladen na detailnější popis jednotlivých studií.

\subsection{OBOR A ÚlOHA}

Všechny studie z fyziky byly zaměřeny na problematiku řešení úloh studentů. Ve třech př́padech se jednalo o úlohy z mechaniky; dvě studie zkoumaly, jak studenti řeší úlohy s elektrickými obvody. Předmětem studie z biologie byl přístup studentů k učení se z powerpointové prezentace obsahující obrázky s různou mírou relevantnosti k prezentovanému textu.

\subsection{VZOREK STUDENTU゚}

Zkoumanými osobami byly v drtivé většině př́padů studenti vysoké školy; počet se pohyboval v rozmezí 11-43. Konkrétnější přehled uvádí tab. 3. 
Tab. 3: Vzorek probandi̊ v realizovaných studiích

\begin{tabular}{lcl}
\hline Studie & Počet studentů & Specifikace \\
\hline Madsen et al., 2012 & 24 & 1. roč. VŠ \\
\hline Smith et al., 2010 & 43 & VŠ \\
\hline Rosengrant, 2001 & 11 & VŠ studenti a zaměstnanci \\
\hline Kozhevnikov et al., 2007 & 15 & VŠ \\
\hline Van Gog, 2005 & 26 & Poslední ročník SŠ \\
\hline Slykhius, 2005 & 15 & Studenti učitelství, VŠ \\
\hline
\end{tabular}

\subsection{TYP VÝZKUMU}

V realizovaných studiích převládá kvantitativní charakter výzkumu a nejčastěji jsou sledovány a posuzovány různé statistické charakteristiky týkající se fixací na předem dané oblasti zájmu výzkumníků, podrobněji viz tab. 4.

Tab. 4: Typy výzkumů v realizovaných studiích

\begin{tabular}{|c|c|c|}
\hline Studie & Typ výzkumu & Stručná specifikace \\
\hline$\overline{\text { Madsen et al., } 2012}$ & kvantitativní & $\begin{array}{l}\text { Posuzování \% času stráveného fixací } \\
\text { oblastí relevantních pro správné } \\
\text { vyřešení problému. }\end{array}$ \\
\hline Smith et al., 2010 & kvantitativní & $\begin{array}{l}\text { Posuzování \% času stráveného fixací } \\
\text { konceptuálních nápověd při učení se ze } \\
\text { vzorově řešených př́kladů. }\end{array}$ \\
\hline$\overline{\text { Rosengrant, } 2001}$ & kvalitativní & $\begin{array}{l}\text { Posouzení strategie přístupu k řešení } \\
\text { úlohy. }\end{array}$ \\
\hline Kozhevnikov et al., 2007 & kvantitativní & $\begin{array}{l}\text { Posuzování počtu fixací ve } \\
\text { vytipovaných oblastech (AOI). }\end{array}$ \\
\hline$\overline{\text { Van Gog, } 2005}$ & kvantitativní & $\begin{array}{l}\text { Posuzování počtu fixací a doby jejich } \\
\text { trvání ve vytipovaných oblastech zájmu } \\
(\mathrm{AOI}) \text {. }\end{array}$ \\
\hline Slykhius, 2005 & $\begin{array}{l}\text { kvalitativní/ } \\
\text { kvantitativní }\end{array}$ & $\begin{array}{l}\text { Posouzení způsobu prohlížení slajdů; } \\
\text { identifikování „průměrné cesty } \\
\text { prohlížení“. Posouzení \% času } \\
\text { stráveného fixací na fotografiích } \\
\text { a dalších částech prezentace. }\end{array}$ \\
\hline
\end{tabular}

\subsection{PouŽITÁ TECHNOLOGIE A ZPRACOVÁNí ZÍSKANÝCH DAT}

Přehled konkrétních očních kamer, které byly použity v realizovaných studiích, a způsob identifikace fixací, případně sakád, uvádí tab. 5 .

\subsection{VÝZKUMNÉ PROBLÉMY A VÝSLEDKY}

Jak už bylo uvedeno výše, typicky se výzkumy v oblasti fyzikálního vzdělávání zaměřily na zkoumání studentů při řešení fyzikálních úloh. Při návrhu experimentu je využiváno paradigma expert-začátečník a při řešení předložených úloh jsou posuzovány strategie používané při řešení těmito dvěma skupinami probandů. Přičemž 
Tab. 5: Technologie a způsob určení fixací/sakád v realizovaných studiích

\begin{tabular}{|c|c|c|}
\hline$\overline{\text { Studie }}$ & Přístroj & Určení fixací a sakád \\
\hline$\overline{\text { Madsen et al., } 2012}$ & $\begin{array}{l}\text { EyeLink 1000, } \\
\text { fixování brady } \\
\text { a čela }\end{array}$ & $\begin{array}{l}\text { Identifikace sakády: pokud pohyb } \\
\text { oka překročil zrychlení } 8500 \% / \mathrm{s}^{2} \\
\text { a rychlost } 30 \% \text { s. V ostatních } \\
\text { př́padech bylo považováno oko za } \\
\text { fixující. }\end{array}$ \\
\hline Smith et al., 2010 & $\begin{array}{l}\text { Tobii } 1750 \\
\text { s volným } \\
\text { pohybem hlavy }\end{array}$ & Neuvádí. \\
\hline$\overline{\text { Rosengrant, } 2001}$ & $\begin{array}{l}\text { Applied Science } \\
\text { Laboratories } \\
\text { Model } 600 \text { Mobile } \\
\text { Contorl Unit, } \\
\text { fixování hlavy }\end{array}$ & Neuvádí. \\
\hline$\overline{\text { Kozhevnikov et al., } 2007}$ & $\begin{array}{l}\text { iView-X RED, } \\
\text { fixování brady } \\
\text { a čela }\end{array}$ & Fixace trvající alespoň $50 \mathrm{~ms}$. \\
\hline$\overline{\text { Van Gog, } 2005}$ & $\begin{array}{l}\text { přístroj od SMI } \\
\text { s frekvencí } \\
\text { snímání } 50 \mathrm{~Hz}\end{array}$ & $\begin{array}{l}\text { Za fixace považovány: alespoň } \\
3 \text { body vzdálené od sebe max. } \\
40 \text { pixelů; doba trvání fixace } \\
\text { alespoň } 100 \text { ms. }\end{array}$ \\
\hline Slykhius, 2005 & ASL Model 501 & $\begin{array}{l}\text { Fixace s dobou trvání alespoň } \\
200 \text { ms. }\end{array}$ \\
\hline
\end{tabular}

dělení na experty a začátečníky je někdy uvedeno na základě výsledků řešení prezentovaných úloh. Za experty jsou považováni studenti s dobrými výsledky, za začátečníky studenti s nejslabším výkonem. Z hlediska obsahové náplně úloh se konkrétně jednalo např́klad o vyhledávání chyby v zapojení schémat elektrických obvodů (van Gog, 2005), o využívání konceptuálních nápověd v řešených př́íkladech z mechaniky (Smith et al., 2010). Madsen et al. (2012) se zaměřili na zkoumání rozdílných druhů pozornosti a jejich vlivu na studenty při řešení úloh z mechaniky. Konkrétní popis výzkumných problémů řešených v šesti studiích a získané hlavní závěry jsou uvedeny dále.

\subsubsection{JAK STUDENTI POSTUPUJÍ PřI UČENÍ SE Z ŘEŠENÝCH ÚLOH Z MECHANIKY?}

Hlavním cílem studie (Smith et al., 2010) bylo analyzování typické aktivity, kterou studenti provádějí, když se učí fyziku, a sice studování řešených úloh. Zejména jak při učení pracují s konceptuálními a matematickými informace a zda účel studia úlohy má vliv na použité strategie.

Z důvodu cíle výzkumu bylo řešení úlohy uspořádáno ve dvou sloupcích, kdy jeden sloupec zahrnoval textové informace související s konceptuálním porozuměním problému a druhý sloupec matematické reprezentace studovaného problému. Tato prostorová separace pak lépe umožnila analyzovat data získaná pomocí oční kamery. Pro odhalení př́padného vlivu účelu studia řešené úlohy na použití strategie byly studentům předloženy řešené úlohy s dvěma rozdílnými zadáními. $\mathrm{V}$ prvním případě 
řešená úloha měla sloužit jako příprava na vyřešení podobné úlohy v následném testu. V druhém prŕípadě student studoval předloženou úlohu proto, aby dobře vyřešil předem zadaný domácí úkol.

Zajímají se studenti vůbec o informace týkající se konceptuálního porozumění problému? Na základě zkušenosti s výukou autoři článku očekávali, že spíše ne. Analýza však odhalila, že studenti strávili fixováním textových informací $40 \pm 3 \%$ z celkového času, který věnovali nápovědám, což je nezanedbatelné procento. Podrobnější analýza přesunů pohledů z jedné (textové/konceptuální) do druhé (matematické) oblasti naznačila, že se studenti při studiu řešených úloh zajímali současně o obě oblasti a nevnímali je jako dva oddělené zdroje informací. Nicméně následný test, který po studentech požadoval vybavení si přečtených informací o podstatě řešeného problému, ukázal, že si toho studenti mnoho nepamatují a to navzdory tomu, že čtením strávili poměrně hodně času. Autoři interpretují tento výsledek dvěma způsoby: bud'to se studenti navzdory čtení informace nic nenaučili nebo po studiu řešeného prŕkladu tyto informace už vypustili.

Učel studia předložených úloh zřejmě nemá vliv na rozsah studia textových informací týkajících se konceptuální podstaty problému. Přestože skupina studentů, kteří studovali řešené problémy za účelem vyřešení domácího úkolu, strávila fixováním textových informací více času, Welchův test rozdíl jako statisticky významný nepotvrdil.

\subsubsection{ROZDÍly VE VIZUÁLNÍ POZORNOSTI STUDENTU゚, KTEŘÍ NE/SPRÁVNĚ ŘEŠILI PŘEDLOŽENÉ FYZIKÁLNÍ PROBLÉMY}

Studie (Madsen et al., 2012) se zaměřila na vizuální pozornost, kterou studenti věnují předložené úloze při jejím řešení. Autoři vycházejí z teorie, která hovoří o dvou typech pozornosti:

1. Bottom-up, která závisí zejména na percepčně výrazných prvcích a je dominantní během prvních dvou sekund prohlížení předloženého materiálu.

2. Top-down naproti tomu nastupuje později a je závislá na přechozích zkušenostech diváka/čtenáře a jeho cílech prohlížení předloženého materiálu.

Cílem studie bylo zjistit, jak tyto dva procesy ovlivňují pozornost studentů při řešení fyzikálních problémů. Hypotézou, očekávaným výsledkem experimentu, byl rozdílně strávený čas fixováním oblastí relevantních, resp. irelevantních ke správnému vyřešení problému studenty, kteří danou úlohu vyřešili správně a studenty, kteří ji naopak vyřešili špatně. Výzkumníci dále hypotetizovali, že studenti, kteří vyřeší danou úlohu špatně, stráví více času na oblastech:

a) odpovídajících typickým miskoncepcím; v tomto př́ípadě bude zaměřená pozornost odpovídat pozornosti typu top-down;

b) odpovídajících percepčně výrazným prvkům; v tomto případě bude pozornost odpovídat pozornosti bottom-up.

Pro zodpovězení výzkumných otázek tedy byly sledovány tyto tři oblasti: relevantní pro správné vyřešení úlohy a oblasti v bodech a) a b). Pro stanovení ploch v bodě a) byly provedeny rozhovory týkající se řešení problémových úloh se třinácti studenty. Na základě př́istupu k řešení u studentů, kteří vyřešili úlohu nesprávně, byly identifikovány př́slušné oblasti. Pro určení ploch uvedených v bodě b) použili autoři program vytvořený v Matlabu (Harel, Koch et al., 2007). Studenti celkem řešili 6 úloh. 
Pro ověření hypotéz provedli autoři studie analýzu rozptylu, která prokázala jak efekt čísla úlohy, tak ne/správnosti vyřešení úlohy na procentu času stráveného na výše uvedených definovaných oblastech. Jednofaktorovou analýzou byl dále zkoumán efekt správnosti odpovědi na závisle proměnnou (tj. procento stráveného času). Studenti, kteří vyřešili úlohu správně, strávili více času na relevantních oblastech, což ukazuje na dominanci pozornosti top-down. Tedy vizuální pozornost těchto studentů byla směřována jejich předchozími zkušenostmi při řešení podobných úloh. Studenti, kteří odpověděli nesprávně, strávili více času prohlížením oblastí odpovídajících typickým miskoncepcím, což opět ukazuje na jejich směřování pozornosti tzv. top-down procesem. I v případě studentů, kteří odpověděli špatně, se zdá, že pozornost není přitahována percepčně výraznými prvky. Rozdíl nebyl prokázán ani pro dobu prvních dvou sekund (od přečtení zadání), což je dle Carmia Itti (2006) limit pro dominanci pozornosti typu bottom-up.

Madsen et al. (2012) dále navrhují možnost, jak pomoci studentům při učení se z výukových materiálů tak, aby byla jejich pozornost směřována na relevantní oblasti obrazového materiálu. Toto ovlivňování je možné realizovat např. užitím vizuálních dynamických nápověd, které mají značnou percepční výraznost.

\subsubsection{ROZDÍly V PROSTOROVÉ PŘEDSTAVIVOSTI STUDENTU゚, KTEŘí NE/SPRÁVNĚ ŘEŠILI PŘEDLOŽENÉ FYZIKÁLNÍ PROBLÉMY}

Studie (Kozhevnikov, 2007) se obecně zaměřila na zjištění vztahu mezi výkonem studentů v testu prostorové představivosti a řešením problémů ve fyzice, konkrétně v kinematice. Tento obor byl vybrán z důvodu velké rozmanitosti externích vizuální reprezentací, které jsou při porozumění tomuto oboru používány (typicky například grafy závislostí kinematických veličin, vektory apod.).

Celkem byly v rámci výzkumu provedeny tři experimenty, metoda oční kamery byla použita $\mathrm{v}$ rámci třetího experimentu. Vlastním experimentům předcházelo přípravné testování, jehož cílem bylo pomocí čtyř testů zaměřených na prostorovou představivost vytipovat studenty s velmi dobrou prostorovou představivostí a naopak studenty, kteří mají tuto schopnost slabší. V prvním experimentu studenti řešili vybrané úlohy z testu Force Concept Investory (Hestenes, 1992; výsledky testování v českém prostředí viz např. Mandíková \& Čížková, 2010) a Kinematics Problem Solving Test. Vybrané úlohy jsou dostupné i v testu Test of Understanding Graphs in Kinematics (Beichner, 1994; český překlad viz Trulikova, 2010). Analýza získaných výsledků ukazuje na korelaci mezi prostorovou představivostí studentů a správností jejich řešení kinematických problémů. Autoři uvádějí dvě možné interpretace výsledků. Jednak studenti s horší prostorovou představivostí mohou mít omezenou kapacitu pracovní paměti týkající se zpracování vizuálních - prostorových podnětů, což jim neumožňuje např. rozdělit křivku v grafu závislosti kinematických veličin na jednotlivé klíčové intervaly a analyzovat pohyb v rámci těchto intervalů. Jednak studenti s lepší prostorovou představivostí mohou mít skrze jejich lepší zkušenost $\mathrm{s}$ vnějším světem vytvořeny sofistikovanější způsoby analýzy pohybu a lepší konceptuální porozumění těmto problémům.

Pro detailnější porozumění sledovaného problému autoři studie provedli další dva následné výzkumy, kdy studenti opět řešili vybrané kinematické problémy z výše popsané studie, lišily se však použité výzkumné metody. Jednak byly realizovány rozhovory se studenty o jejich konkrétním řešení jednotlivých problémů. Dále byla použita metoda sledování očních pohybů studentů. Tento třetí experiment se zaměřil pouze na sledování strategie studentů při řešení dvou úloh z předchozí sady. 
První se týkala předpovědi pohybu puku, pokud do něho praštíme silou v určitém směru. Ve druhé úloze měli studenti popsat pohyb znázorněný grafem závislosti prostorové souřadnice na čase. Pro potvrzení nebo vyvrácení výzkumných hypotéz byly definovány oblasti zájmu (region of interest - ROI) a sledován počet fixací v těchto regionech. V případě úlohy s pukem všichni studenti s identifikovanou horší prostorovou představivostí vyřešili tuto úlohu chybně a pohyby jejich očí nepredikovaly pohyb puku v požadovaném směru. Sedm z devíti studentů s dobrou prostorovou představivostí vyřešili úlohu správně a vykazovali fixace ve směru uvažovaného pohybu puku.

V případě úlohy s grafem závislostí kinematických veličin byly podrobněji analyzovány pouze výsledky studentů s horší prostorovou představivostí, kteří vyřešili úlohu nesprávně a projevili typickou miskoncepci vnímání grafu jako obrázku, a studentů s dobrou prostorovou představivostí, kteří vyřešili úlohu správně. Jako oblasti zájmu byly definované: osy grafu, popisy os a čára grafu. Pro ověření stanovených hypotéz byla uvažována procenta fixací a procenta celkového času, který studenti strávili při prohlížení jednotlivých oblastí (procenta vždy vztažená k celkovému počtu fixací a k celkovému času prohlížení grafu). Výsledky získané pomocí analýzy rozptylu ukázaly, že studenti řešící úlohu správně strávili více času prohlížením os než studenti řešící ji špatně, přičemž popisu os věnovali stejnou pozornost. Tento výstup analýzy může ukazovat na abstraktní př́istup ke grafưm ze strany správně řešících studentů, kdy při popisu pohybu zobrazeném v grafu křivku grafu rozdělí na úseky (dle měnící se rychlosti) a interpretují pohyb pro každý úsek zvlášté. Zatímco studenti s výše uvedenou miskoncepcí zřejmě mají tendenci vnímat a interpretovat křivku pohybu jako celek.

\subsubsection{PřÍSTUPY K ŘEŠENÍ ÚLOH ZAMĚŘENÝCH NA ELEKTRICKÉ OBVODY ZAČÁTEČNÍKY A ODBORNÍKY}

Návrh výzkumu studie (Rosengrant, 2009) vychází z typického paradigmatu výzkumů realizovaných pomocí oční kamery (viz např. Gegenfurtner, 2001), a sice že přístup $\mathrm{k}$ řešení problémů je mezi odborníky a začátečníky v dané oblasti rozdílný. Cílem studie tedy bylo srovnání způsobu řešení experty a začátečníky. Respondenti řešili celkem čtyři úlohy zaměřené na elektrické obvody. Typickým problematickým konceptem v této oblasti je koncept proudu, proto úlohy sledovaly porozumění tomuto konceptu. Data získaná pomocí oční kamery ukázala tyto dva rozdíly týkající se strategie řešení:

1. Experti vykázali větší počet přesunů mezi zadáním a schématem elektrického obvodu.

2. Po skončení řešení experti ještě jednou přehlédli celé řešení příkladu, začátečníci nikoliv.

Co se týče vlastního řešení problému, experti při sledování schématu a promýšlení řešení sledovali vždy celou smyčku obvodu, což naznačuje, že sledovali jakousi pomyslnou cestu proudu. Naproti tomu začátečníci víceméně fixovali vždy pouze jednotlivé značky rezistorů $\mathrm{v}$ daných schématech. $\mathrm{V}$ případě uvedeného výzkumu je nutné brát $\mathrm{v}$ úvahu velmi malý vzorek expertů, který se účastnil výzkumu (pouze dva respondenti). Výsledky je proto možné chápat pouze jako možné hypotézy pro další experimentování. 


\subsubsection{PříSTUPY K ŘEŠENÍ PROBLÉMOVÝCH ÚLOH ZAMĚŘENÝCH NA ELEKTRICKÉ OBVODY ZAČÁTEČNÍKY A ODBORNÍKY}

Dalším výzkumem z oblasti učiva o elektřině a magnetismu je studie van Goga (2005), která se zabývá rozdíly při řešení problémových úloh mezi studenty středních škol s různou mírou odbornosti v daném předmětu. Úlohy byly prezentovány jako počítačově simulované modely elektrických obvodů s nějakou chybou, kterou bylo třeba odhalit. Jednalo se např́iklad o špatně zapojenou baterii, zkrat v obvodu apod. Při přemýšlení studentů během řešení byly identifikovány tyto fáze:

1. orientace v problému,

2. formulování problému a rozhodnutí se pro nějakou první akci,

3. zhodnocení výstupu, který tato akce přinesla, a rozhodnutí se pro další akce,

4. konečné zhodnocení řešení problému.

Výzkum nespočíval pouze v metodě sledování očních pohybů, studenti byli také požádáni o popis vlastní strategie řešení problému nahlas. Z 26 účastníků byli pro další výsledky vybráni studenti s nejvyšší a nejnižší mírou expertnosti v dané skupině. Míra expertnosti byla posuzovaná na základě výsledků řešení celého testu.

Pro ověření hypotéz byly vytipovány oblasti zájmu (area of interest) a výsledky byly určeny na základě rozdílů celkové doby strávené prohlížením jednotlivých oblastí mezi dvěma skupinami studentů, na základě rozdílů v průměrné době trvání fixací a v počtu fixací $\mathrm{v}$ jednotlivých fázích řešení problému. Pro zjištění statistické významnosti rozdílů byl použit (vzhledem k velikosti vzorku) neparametrický Mann-Whitneyův test.

Studenti identifikovaní jako experti strávili více času ve fázi jedna, tj. v zorientování se v problému. Tito studenti také během této fáze vykázali větší počet fixací na baterii v obvodu, což byl chybně zapojený prvek v obvodu, než méně expertní studenti. Nicméně průměrná doba fixace pro více expertní studenty byla statisticky významně nižší než v dalších fázích, zatímco pro méně expertní studenty rozdíl mezi jednotlivými fázemi prokázaný nebyl. Kratší průměrná doba fixace zřejmě odpovídá pouze procesu dekódování zobrazené informace-schématu, zatímco delší průměrná doba fixace spíše odpovídá procesům vlastního řešení problému. V případě druhé fáze nebyly zaznamenány statisticky významné rozdíly v přístupu obou skupin studenti̊. Více expertní respondenti strávili více času ve tř̌etí fázi, nicméně rozdíl v průměrné době trvání fixací v této fázi statisticky významný nebyl.

\subsubsection{POSOUZENÍ VHODNOSTI DOPROVODNÝCH FOTOGRAFIÍ V POWERPOINTOVÉ PREZENTACI}

Poslední prezentovaná studie (Slykhuis et. al, 2005) se obsahově týká biologie, konkrétně biologické diverzity, a byla zaměřena na porovnání pozornosti, kterou studenti věnují fotografiím umístěným v powerpointové prezentaci. Cúlem bylo posoudit, zda existuje zejména rozdíl v pozornosti mezi fotografiemi s rozdílnou mírou dekorativnosti. Pro klasifikaci fotografií byla převzata klasifikace fotografií v textu, kterou navrhl Pozzer a Roth (2003). Autoři rozlišují 4 stupně dekorativnosti fotografie: dekorativní, ilustrativní, vysvětlující a doplňující (viz tab. 6). Probandi posuzovali prezentaci obsahující celkem 16 slidů, z toho 2 pouze textové, 2 pouze obrázkové a 12 smíšených.

Polovina studentů se v rámci výzkumu učila pouze z prezentace, druhá polovina studentů k prezentaci obdržela i předem nahraný slovní komentár. Analyzována byla pouze data pro fotografie zařazené do nejvzdálenějších kategorií klasifikace (tj. pro 
Tab. 6: Klasifikace fotografií v textu dle Pozzer a Roth (2003)

\begin{tabular}{lcccc}
\hline $\begin{array}{l}\text { Kategorie } \\
\text { fotografie }\end{array}$ & dekorativní & ilustrativní & vysvětlující & doplňující \\
\hline Odkaz v textu & není & není & není & je \\
\hline Nadpis & není & je & je & je \\
\hline & & & Navíc je uveden & Je uveden \\
& & & vysvětlující & vopis obrázku.tlující \\
& & & popis obrázku.
\end{tabular}

dekorativní a doplňující fotografie). Získaná data byla analyzována dvěma způsoby kvantitativně a kvalitativně.

V rámci kvantitativního př́stupu byly vymezeny oblasti zájmu a srovnáním statistických charakteristik pro porovnávané fotografie (\% času stráveného prohlížením/fixacemi fotografie během prvních pěti sekund prohlížení slidu, \% času stráveného prohlížením/fixacemi fotografie během celého prohližžní slidu) byly zjištovány př́padné rozdíly. Jako oblasti zájmu byly definovány: nadpis, text, obrázek, zbývající prostor na obrazovce, pohled mimo obrazovku. Poměrně nepřekvapivě doplňující fotografie získaly od studentů více pozornosti než fotografie pouze dekorativní. Studenti tyto fotografie častěji fixovali a jejich prohlížením celkově strávili více času. Tyto rozdíly byly zjištěny jak pro celou dobu prohlížení slidu, tak i pouze pro dobu prvních pěti sekund, která byla považována za dobu typickou pro získání prvního přehledu, co vše daný slide obsahuje.

Cílem kvalitativního posouzení bylo zjištění, zda žáci přistupovali k prohlížení rozdílně. Konkrétně se jednalo o určení „průměrného“ způsobu prohlížení; o určení „průměrné“ cesty prohlížení slidu. Výzkumníci se zaměřili pouze na prvních 10 fixací, které se udály většinou během prvních pěti sekund. Každá fixace byla přiřazena $\mathrm{k}$ jedné z pěti definovaných AOI a jako míra centrální polohy byl určen modus. Podobný způsob prohlížení byl zjištěn pro slidy s oběma typy fotografií. Nicméně pro slide s dekorativními fotografiemi je typické, že se studenti k těmto fotografiím již nevracejí. Další kvalitativní posouzení se týkalo způsobu prohližení slidů prezentace bez a se zvukovým komentářem.

\section{LIMITY DANÉ METODY}

Jak bylo uvedeno v předchozích kapitolách, metodu oční kamery je možné použít různými způsoby a pro různé typy výzkumů. V rámci diskuze limitů této metody se omezíme na použití kamery zpo̊soby realizovanými v rámci studií uvedených v přehledu předchozí kapitoly, tj. na použití kamery diagnostickým zpơsobem s prezentací statických vizuálních materiálů.

Velmi často se metody využivá ke zjištování strategií probandů při prohlížení předložených materiálio s cílem vyřešit zadané úlohy. Tato metoda do určité míry může nahradit metodu tzv. myšlení nahlas (angl. think aloud protocol), kdy pokusná osoba během řešení dané úlohy přemýšlí nahlas, aby mohly být její myšlenky zaznamenány. Tento přístup má samozřejmě omezení, konkrétně se jedná zejména o možnost cenzury myšlenky pokusnou osobou a dále o navýšení kognitivní zátěže pokusné osoby, která je zapříčiněna nutností formulace myšlenek a jejich vyslovením nahlas. Při použití metody oční kamery jsou tyto problémy eliminovány. Zde je sledování kognitivních procesů odvozováno z očních pohybů. Hypotézu, že místo, kam směřuje pohled pokusné osoby, je také touto osobou vnímáno, nastínili již před tři- 
ceti lety Just a Carpenter (1976). V současné době je zřejmé, že tuto hypotézu nelze zcela přijmout a zaměření pozornosti může být směřováno i do jiných oblastí. Dalším souvisejícím problémem je zjištění, co a jak si pokusná osoba o vnímané oblasti myslí, pocituje. Možností, jak se snažit eliminovat tyto nedostatky, je několik. V prvé řadě je možné metodu kombinovat s metodou myšlení nahlas. Zde ovšem máme navíc již zmíněnou kognitivní zátěž a tedy nereálné podmínky řešení problému. Další možností může být zpětné sledování a komentování vlastního záznamu pokusnou osobou. V některých typech výzkumů se jeví jako přínosné současně zaznamenávat aktivitu mozku a sledovat zapojení jednotlivých mozkových oblastí (Duchowski, 2002).

V rámci diskuze omezení metody nesmí chybět diskuze ohledně přesnosti metody. Jak už bylo uvedeno v úvodní části článku, přesnost technologického zařízení (vlastní kamery) není to jediné, co ovlivňuje získané výstupy. Pozice očí je snímaná s frekvencí, která se obvykle pohybuje v rozmezí $60-500 \mathrm{~Hz}$, což odpovídá snímání každých 17-2 ms. Jelikož se za minimální běžnou dobu trvání fixace považuje $150 \mathrm{~ms}$, při určování fixace se tak lze opřít o 9-75 získaných pozic očí. Případné mrknutí oka apod. může znemožnit získání dat, proto je důležité jako validní data uvažovat ta, kde procento získaných pozic očí je dostatečné, obvykle se uvažuje více než $75 \%$. Zde samozřejmě záleží na použité frekvenci a cílech výzkumu. Relevantnost získaných dat je také dále ovlivněna možností pokusné osoby pohybovat hlavou. Pro dosažení kontroly nad pohybem očí se velmi často hlava probanda zafixuje. Nicméně tento přístup v sobě nese poměrně velkou nevýhodu, a sice nepřirozené podmínky probanda při řešení úkolu. Při návrhu experimentu je tedy důležité zvažovat nejen hledisko přesnosti, ale také validnosti získaných dat. Fixování pozice hlavy se ukazuje jako nezbytné při výzkumech čtení. Výstupy v podobě identifikovaných fixací jsou určitě ovlivněny algoritmem, který k identifikaci fixací výzkumník použije. Podobně jako v př́padě posuzování výběru statistické metody, i zde se jako účelné jeví prvotní kvalitativní posouzení hrubých dat, tj. pozic očí, a následná konfrontace různých použitých algoritmů.

V první kapitole je uveden typický návrh experimentu, který se opírá o paradigma expert-začátečník. Pro každý návrh výzkumu je klíčová definice experta. V psychologických studiích se typicky expertem rozumí odborník, který se excelentně orientuje v předložených grafických materiálech. Např. experti radiologisté jsou schopni detekovat rakovinu na mamografu během zlomku sekundy. Obvykle tito odborníci vykazují 10 let praxe s daným obrazovým materiálem (Gegenfurtner, 2011). V oblasti fyzikálního vzdělávání, jak je patrné i z předchozích ukázek návrhů realizovaných výzkumů, je expertství uvažováno spíše v rovině konceptuálního porozumění řešenému problému, které se pak promítá do práce s grafickým materiálem. Např́klad ve výzkumné studii van Goga (2005) zřejmě nelze očekávat, že by daný expert vyhodnocoval elektrické obvody z hlediska jejich funkčnosti tak intenzivně, jako během své práce posuzuje radiolog mamografické zobrazení. V případě výzkumů v oblasti školního vzdělávání se ukazuje jako užitečné rozlišovat i expertství z hlediska řešení problémů. Přehled typických rozdílů mezi experty a začátečníky uvádí např. Gerace (2001). Jak vyplývá z přehledu designu výzkumů uvedených výše, často je pak expertství posuzováno na základě výkonu v daném testu nebo v dané úloze. Volbu kritéria je samozřejmě nutné dobře zvážit; jak naznačuje kvalitativní analýza výsledků (Kekule, 2014), v případě některých úloh můžeme dostat velmi rozdílné výstupy.

Výše diskutované problematické oblasti prezentované metody je nutné brát v úvahu při interpretaci získaných výsledků. 


\section{ZÁVĚR}

Metoda výzkumu pomocí oční kamery je velmi dobře etablovaná ve výzkumu v psychologii, marketingu; v oblasti vzdělávání ve sportu. Jak ukazují prezentované studie zaměřené zejména na řešení úloh z mechaniky a elektřiny, metoda může přinést užitečné výsledky s výstupy do praxe i v oblasti fyzikálního vzdělávání. Je možné ji použít jak při realizaci kvalitativního, tak kvantitativního výzkumu. Typické paradigma expert-začátečník stojící v pozadí návrhů výzkumů z kognitivní psychologie se ve studiích ve fyzikálním vzdělávání týká strategií a konceptuálního porozumění předloženým problémovým úlohám.

\section{LITERATURA}

Beichner, R. J. (1994). Testing student interpretation of kinematics graphs. American Journal of Physics, 62, 750-762.

Bojko, A. (2013). Eye tracking the user experience: A practical guide to research. Rosenfeld Media.

Carmi, R. \& Itti, L. (2006). Visual causes versus correlates of attentional selection in dynamic scenes. Vision Research, 46, 4333-4345.

Duchowski, A. (2006). Eye tracking methodology. Theory and practice. 2nd edition, Springer.

Duchowski, A. (2002). A breadth-first survey of eye-tracking applications. Behavior Research Methods, InstrumentsEC Computers, 34(4), 455-470.

Gegenfurtner, A., Lehtinen, E. \& Saljo, R. (2011). Expertise differences in the comprehension of visualizations: a meta-analysis of eye-tracking research in professional domains. Educational Psychology Review, 23, 523-552.

Gerace, W. J. (2001). Problem solving and conceptual understanding. Proceedings PERC 2001. Dostupné z http://umperg.physics.umass.edu/writings/online

Graesser, A. C. (2005). Question asking and eye tracking during cognitive disequilibrium: Comprehending illustrated texts on devices when the devices break down. Memory \& Cognition, 33(7), 1235-1247.

Harel, J., Koch, C. \& Perona, P. (2007). Graph-based visual saliency. In Scholkopf, B., Platt, J. \& Hoffman, T. (Eds.), Advances in neural information processing systems 19, Cambridge: MIT Press. 545-552.

Hestenes, D., Wells, M. \& Swaxkhamer, G. (1992). Force concept inventory. American Journal of Physics, 30, 141-154.

Just, M. A. \& Carpenter, P. A. (1976). Eye fixation and cognitive processes. Cognitive Psychology, 8, 441-480.

Kekule, M. (2014). Students' approaches when dealing with kinematics graphs explored by eye-tracking research method. In Bilsel, A., Garip, M. U. (Eds.), Proceedings of the frontiers in mathematics and science education research conference, FISER' 2014.

(108-117). Science Education research Group as Eastern Mediterranean University: Famagusta.

Kozhevnikov, M., Motes, M. \& Hegarthy, M. (2007). Spatial visualization in physics problem solving. Cognitive Science, 31, 549-579. 
Lukavský, J. (2005). Sledování očních pohybi̊. [Bakalářská práce]. MFF UK, Praha.

Madsen, A. M., Larson, A. M., Loschky, L. C. \& Sanjay Rebello, N. (2012). Difference in visual attention between those who correctly and incorrectly answer physics problems. Physical Review Special Topics - Physics Education Research, 8. Dostupné z DOI: 10.1103/PhysRevSTPER.8.010122

Mandíková, D. \& Čížková, D. (2010). Prekoncepce studentů o síle a pohybu - výsledky testu FCI. PMFA, 55(2), 148-154.

Miellet, S., O'Donnell, P. J. \& Sereno, S. C. (2009). Parafoveal magnification: Visual activity does not modulate the perceptual span in Reading. Psychological Science, 20, $721-728$.

Pozzer, L. L. \& Roth, W. M. (2003). Prevalence, function, and structure of photographs in high school biology textbooks. Journal of Research in Science Teaching, 40, $1089-1114$.

Rosengrant, D., Thomson, C. \& Mzoughi, T. (2009). Comparing experts and novices in solving electrical circuit problems with the help of eye-tracking. In Sabella, M., Henderson, C. \& Singh, C. (Eds.), Proceedings of the 2009 Physics Education Research Conference, (249-252). New York: American Institute of physics. Mellville.

Slykhuis, D. A., Wiebe, E. N. \& Annetta, L. A. (2005). Eye-tracking students' attention to PowerPoint photographs in a science education setting. Journal of Science Education and Technology, 14 (5/6). Dostupné z DOI:10.1007/s10956-005-0225-z

Smith, A., Mestre, J. \& Ross, B. (2010). Eye-gaze patterns as students study worked-out examples in mechanics. Physical Review Special Topics - PER, 6, DOI:

10.1103/PhysRevSTPER.6.020118

Trulikova, B. (2010). Miskoncepce žáků a studentio při interpretaci kinematických grafi̛. [Bakalářská práce]. Matematicko-fyzikální fakulta UK Praha.

Van Gog, T., Paas, F. \& Van Merrienboer, J. (2005). Uncovering expertise-related differences in troubleshooting performance: Combining eye movement and concurrent verbal protocol data. Applied Cognitive Psychology, 19, 205-221.

MARTinA KEKULE, martina.kekule@seznam.cz

Univerzita Karlova v Praze, Matematicko-fyzikální fakulta

Katedra didaktiky fyziky

V Holešovičkách 2, 18000 Praha, Česká republika 